\title{
Manitoba's endangered alvars: an initial description of their extent and status
}

\author{
Rebekah Neufeld ${ }^{1, *}$, Cary Hamel ${ }^{2}$, and Chris Friesen ${ }^{3}$ \\ ${ }^{1}$ Nature Conservancy of Canada, Manitoba Region, 207 - 1570 18th Street, Brandon, Manitoba R7A 5C5 Canada \\ ${ }^{2}$ Nature Conservancy of Canada, Manitoba Region, 200 - 611 Corydon Avenue, Winnipeg, Manitoba R3L 0P3 Canada \\ ${ }^{3}$ Manitoba Conservation Data Centre, P.O. Box 24, 200 Saulteaux Crescent, Winnipeg, Manitoba R3J 3W3 Canada \\ ${ }^{*}$ Corresponding author: Rebekah.Neufeld@natureconservancy.ca
}

Neufeld, R., C. Hamel, and C. Friesen. 2018. Manitoba's endangered alvars: an initial description of their extent and status. Canadian Field-Naturalist 132(3): 238-253. https://doi.org/10.22621/cfn.v132i3.1865

\begin{abstract}
Alvars are rare in Canada and uncommon globally. This study represents the first formal attempt to describe and delineate the extent of alvars in Manitoba. A systematic examination of the Interlake region's edaphic and biological characteristics, using a geographic information system, resulted in the identification of 67 sites warranting further field study. Of these sites, 61 were surveyed and information was collected on vegetation composition and structure, soil characteristics, land ownership, and land use. Alvar was confirmed at 28 sites, extending over approximately 3930 ha in five geographically distinct clusters. Four putative types of alvar communities are described: grassland, shrubland, savannah, and wetland. Livestock grazing is the dominant land use and occurs across more than three-quarters of Manitoba alvar. Approximately $12 \%$ coincide with mining claims or quarry leases. Two-thirds occur on publicly owned land.
\end{abstract}

Key words: Alvar; karst; endangered ecosystem; Manitoba; Interlake; limestone; dolomite

\section{Introduction}

Alvars are globally uncommon ecosystems that are distinctive for their unusual plant species composition and associations and natural openness in otherwise forested regions (Catling and Brownell 1995; Reshcke et al. 1999), although alvar woodlands and the associated successional stages are also important components (Catling and Brownell 1999a; Catling et al. 2002; Brunton and Catling 2017). Alvars have thin or absent soils underlain by flat limestone or dolomitic bedrock that restricts drainage; thus, they are subject to extreme variations in moisture availability that range from drought conditions to periodic flooding (Brunton 1988; Catling and Brownell 1995; Reschke et al. 1999; Catling 2009a). The physical structure and species composition of alvar plant communities can vary; Great Lakes alvars, for example, have been differentiated into 13 types (Reschke et al. 1999). In Manitoba, alvar-like ecosystems that support species characteristic of both prairie and boreal forest, with a limited occurrence of trees and occasional exposure of dolomitic pavement, have been described (Hamel and Foster 2004).

In Canada, alvars are found in the Great Lakes region, Quebec (Reschke et al. 1999), and the Northwest Territories (Catling 2009a). The presence of alvar in Manitoba was noted by Catling (2009a), but no information on its extent was provided. Although the precise extent of alvars in North America is not yet known, their distribution is fragmented and loosely follows the edge of the Canadian Shield where postglacial meltwaters have exposed limestone bedrock (Catling 2009a). Before our study, alvar-like ecosystems associated with near-surface dolomitic limestone pavement and inland cliffs had been documented at five locations in Manito- ba between the southern basins of Lakes Manitoba and Winnipeg, i.e., the Interlake region (Hamel and Foster 2004). In 2011, an Ontario alvar expert (John Riley) accompanied us to one of these locations and confirmed that the ecosystem shared characteristics consistent with alvar ecosystems in Ontario and were worthy of further study and formal description.

In 2015, the Manitoba government listed alvar as endangered under the Manitoba Endangered Species and Ecosystems Act using the authors' unpublished information to support determination of its conservation status.

The results of this study were previously published in a technical report (Manitoba Alvar Initiative 2012). This paper refines those results and confirms the findings in the context of the established body of knowledge on North American alvars. The objectives of this study were to survey and map alvars in the Interlake region of Manitoba; to describe their physical structure and species composition; and to determine land ownership and land uses of Manitoba alvars.

\section{Methods}

We used a geographic information system (GIS) to identify and delineate 67 sites of potential alvar encompassing 6313 ha (Figure 1) in the south Interlake and adjacent regions. We examined spatial data layers of geomorphologic and vegetative features representative of alvar-like sites identified by Hamel and Foster (2004). Layers included orthophotographs (to assess vegetation cover), soil classification data (to determine soil depth and the presence of near-surface limestone bedrock), and a digital elevation model (to identify the location of ridges; Manitoba Conservation and Water 


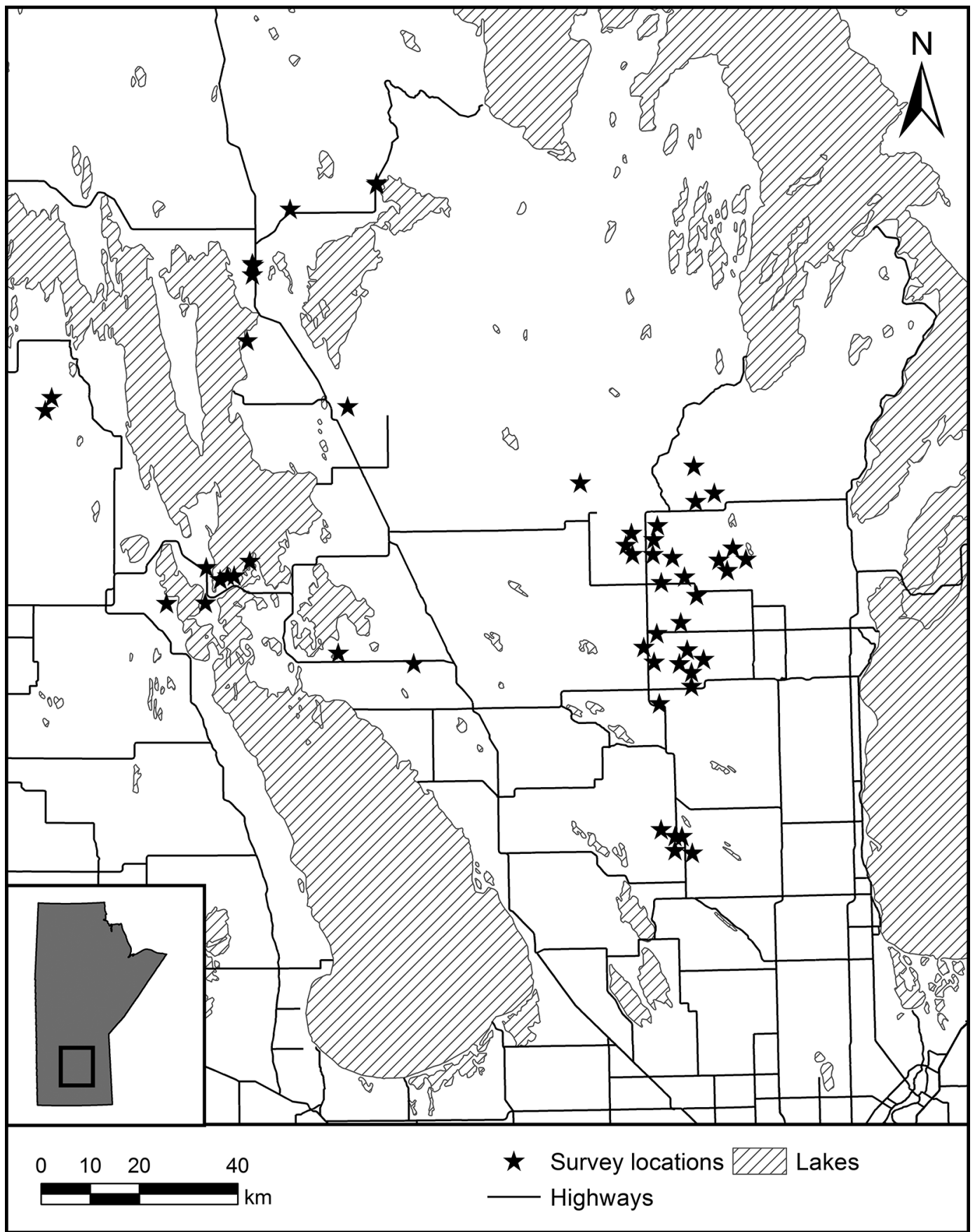

FIGURE 1. Survey locations (stars) were considered potential locations for alvar based on similarities in geological and soil characteristics to previously confirmed communities in Manitoba.

Stewardship 2012a). Between June and August 2012, we surveyed and assessed 61 sites to determine whether they supported alvar. We attempted to visit all potential sites regardless of ownership, but we did not receive permission to access six private land parcels.

A site was determined to be alvar if it met the following criteria: presence of flat limestone or dolomite bed- rock that restricts drainage; soil thin —with a depth up to $15 \mathrm{~cm}$ that is not the result of mechanical removal —or absent (criterion used by Brunton 1988; Catling and Brownell 1995; Reschke et al. 1999); and tree canopy cover $<60 \%$ (criterion used by Reschke et al. 1999). Although alvars can occur on soil deeper than $15 \mathrm{~cm}$ (Reschke et al. 1999), such sites were not in- 
cluded in the estimation of extent for this study because they could not be confirmed as being alvars without more detailed analyses of the species composition and/or investigation of other ecologically distinct characteristics resulting from the influence of an underlying bedrock pavement.

If not visible at the surface, limestone pavement was detected by digging small test holes. We determined soil depth by pressing a metal rod into the soil and measuring depth at impact with bedrock. Evidence of extreme moisture variability was based on observations of standing water following rain events, the presence of algae on dry pavement, thin bare soil (without evidence of disturbance), and restricted vegetation and lichen growth patterns. We recorded qualitative observations of the dominant plant species, soil depth, unique topographic features, land use, and patterns of flooding, drought, and drainage.

The potential extent of alvar at each survey site was mapped as polygons in GIS. Boundaries were delineated by using ground-truthed global positioning system coordinates and interpreting orthophotographs. These maps indicate the estimated maximum extent of the alvar communities observed. Within mapped habitat patches, there may be areas without alvar, or an area may represent a mosaic of alvar and other ecosystems.

Dominant physiognomic characteristics were used to categorize alvars into types to better describe the variation observed. Alvar types were characterized first by growth form (tree, shrub, forb, or graminoid), then vertical structure $(<10 \%$ tree canopy or $10-60 \%$ tree canopy, comparable to thresholds used to distinguish savannah from other upland ecosystems found in the Interlake region; Minnesota Department of Natural Resources 2005), and, finally, by wetland or upland species affinities. Putative descriptions of each type's composition and variation were prepared using the data collected during site surveys. We used vegetation survey plots at a small sample of sites to supplement the general survey data and test the accuracy of these descriptions. Nine $20 \mathrm{~m} \times 50 \mathrm{~m}$ plots, distributed among four sites, were randomly placed in what appeared to be unique subtypes of alvar. Each plot was divided into six subplots: one $20 \mathrm{~m} \times 20 \mathrm{~m}$; four $10 \mathrm{~m} \times 10 \mathrm{~m}$; and one $20 \mathrm{~m} \times$ $10 \mathrm{~m}$. The canopy cover of vascular plants, bryophytes, and lichens was recorded by visual observation within the four $10 \mathrm{~m} \times 10 \mathrm{~m}$ subplots using the following cover classes: $<0.1 \%, 0.1$ to $<1 \%, 1$ to $<2 \%, 2$ to $<5 \%, 5$ to $<10 \%, 10$ to $<25 \%, 25$ to $<50 \%, 75$ to $<95 \%$ and $\geq 95 \%$. The additional two plots were used to capture the cover class of any species not recorded in the initial four plots. Soil depth was recorded on the centre line and at $10 \mathrm{~m}$ and $30 \mathrm{~m}$ along the plot starting from the $10 \mathrm{~m} \times 20 \mathrm{~m}$ end. Voucher specimens obtained for vascular plants, bryophytes, and lichens were deposited in the University of Manitoba herbarium (WIN). A statistical analysis was not completed.
The bedrock composition of the limestone underlying alvar was compared at each site by overlaying the mapped alvar polygons with a GIS shapefile of the geological periods of bedrock formation (Manitoba Mineral Resources $2012 \mathrm{a}$ ) to identify patterns related to alvar type and distribution.

\section{Results and Discussion \\ Extent and distribution}

Alvar was found at 28 of the 61 survey locations, with a maximum extent of $\sim 3934$ ha. Alvars $>16$ ha often supported internal patches of non-alvar ecosystems, such as forest or prairie, where soil depth was greater than $15 \mathrm{~cm}$.

We mapped 101 spatially distinct units of alvar, varying from 0.4 ha to 809 ha and grouped these units into five geographically distinct sites (Figure 2). The Marble Ridge Alvar, referred to as Marble Ridge A, $\mathrm{B}$, and C Alvars, follows a limestone formation of the same name, along which inland limestone cliffs are also found. The Peguis Alvar is immediately east of the Peguis First Nation Reserve, and the Sylvan Alvar is almost completely within the boundaries of the Sylvan Dale Community Pasture. The Poplarfield Alvar represents a group of small, isolated units near Poplarfield. The Clematis Alvar is located in and around the Clematis and Sandridge Wildlife Management Areas.

\section{Alvar types}

Alvars were categorized into four putative types: grassland (graminoid dominated, $<10 \%$ tree cover, upland affinity), shrubland (shrub dominated, $<10 \%$ tree cover, upland affinity), savannah (shrub dominated, $>10 \%$ tree cover, upland affinity), and wetland (graminoid dominated, $<10 \%$ tree cover, wetland affinity). Many sites supported multiple types of alvar occurring in combination. A list of plant and lichen species observed in each alvar type is shown in Table 1, but quantitative values are not presented as the plot data are not fully representative of the variation that exists within the types described.

Grassland alvars have nearly continuous vegetative cover, with soil depth typically ranging from $5 \mathrm{~cm}$ to $10 \mathrm{~cm}$, and only occasional patches of limestone pavement (Figure 3 ). They are dominated by upland graminoid species, with high forb and low shrub cover. Trees are typically absent or restricted to the periphery. Moss provides significant ground cover among and beneath other vegetation. Bare soil, exposed limestone, and bryophyte and lichen growth directly on the limestone pavement were uncommon. These sites are generally flat, although some areas have small (typically $<1 \mathrm{~m}$ in height) outcrops along the edges of plateau formations. We observed less evidence of flooding following rain compared with other alvars, although drainage is restricted and water pools on the limestone pavement. We did not observe conditions immediately following spring melt. 


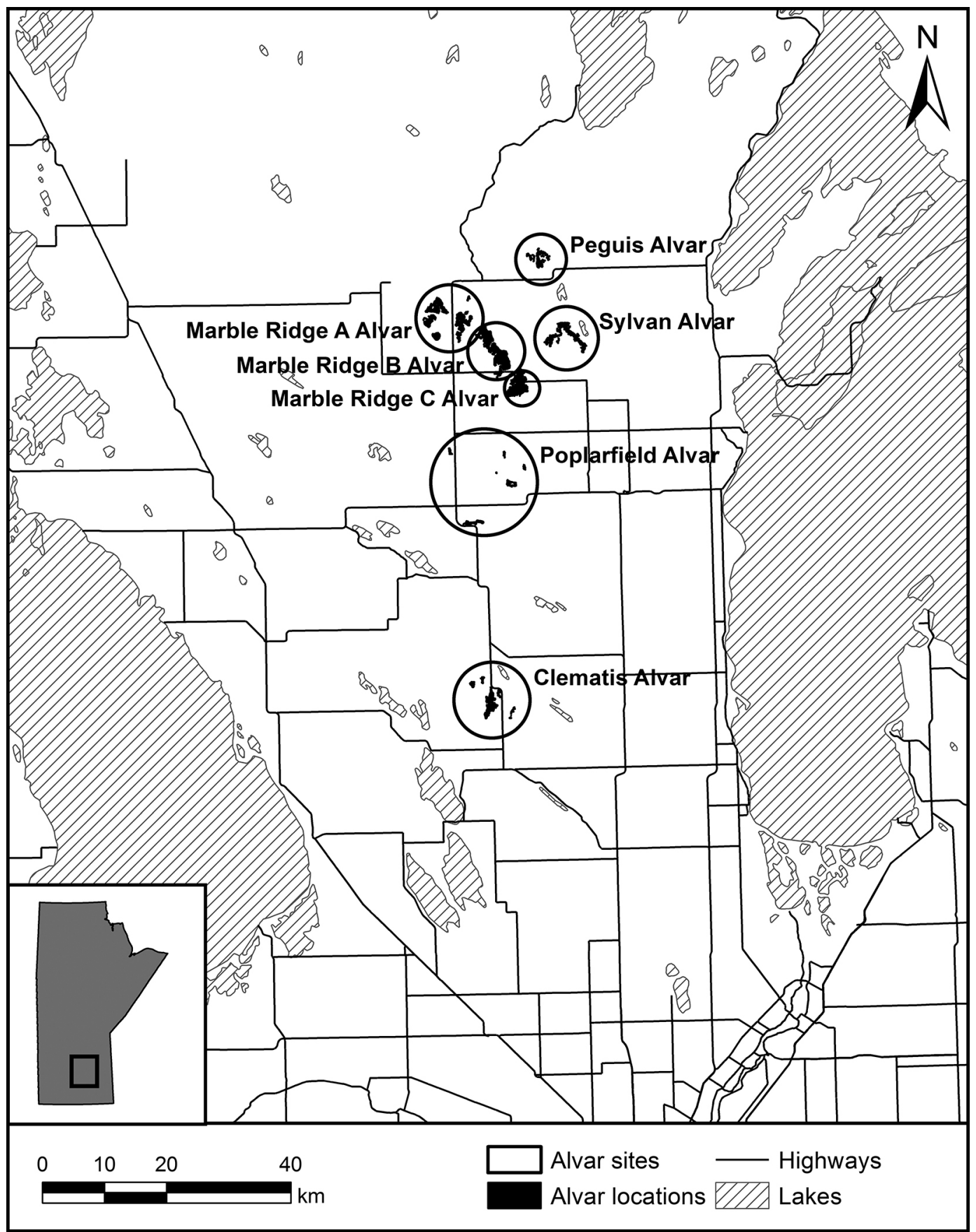

FIGURE 2. Confirmed locations of alvar in Manitoba. Individual patches of alvar have been grouped into five sites. Marble Ridge $\mathrm{A}, \mathrm{B}$, and $\mathrm{C}$ together constitute a single site.

In shrubland alvars (Figures 4, 5, and 6) vegetative cover is generally patchy and often restricted to cracks and seams in the bedrock with deeper soils. Soil depth is shallower than in grassland alvars, typically $<5 \mathrm{~cm}$, and limestone pavement is frequent. Shrubs are the dominant vascular plant cover, followed by forbs, with graminoids frequent, but not as abundant as in grassland alvars. Tree cover is greater than in grassland alvars, but still low, and trees generally appear to be stunted. Cover of bryophytes, lichens, and bare soil is much higher 


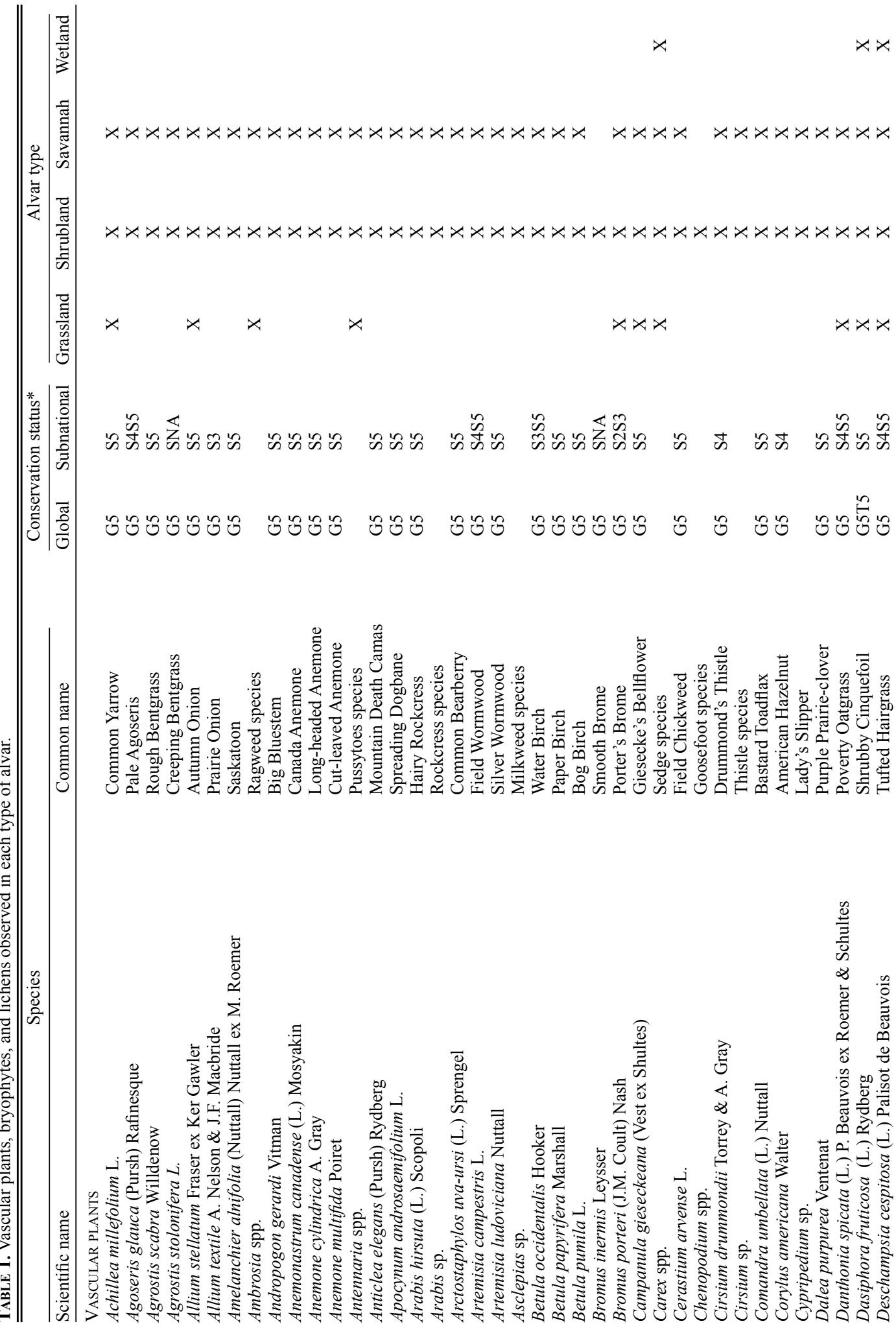




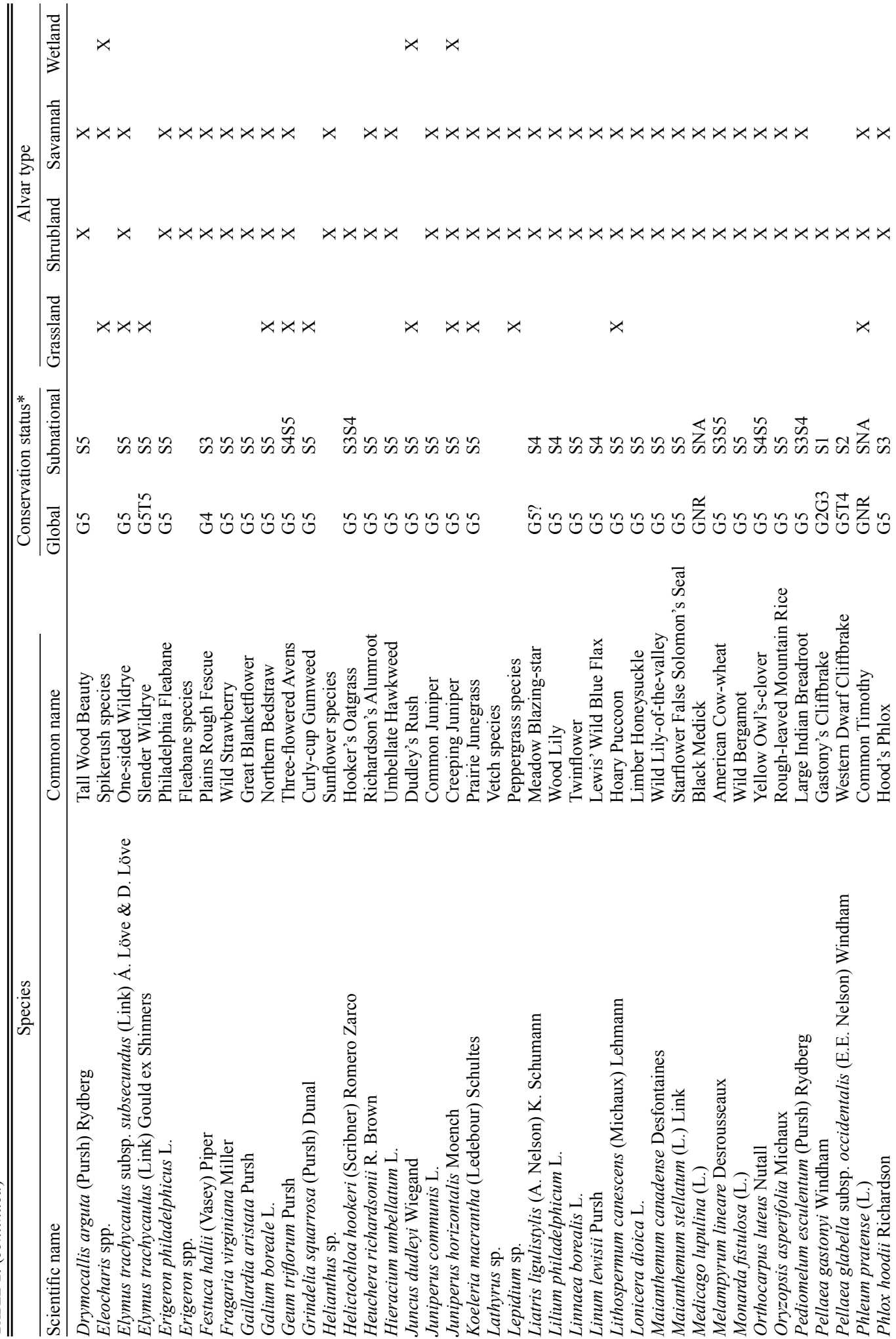




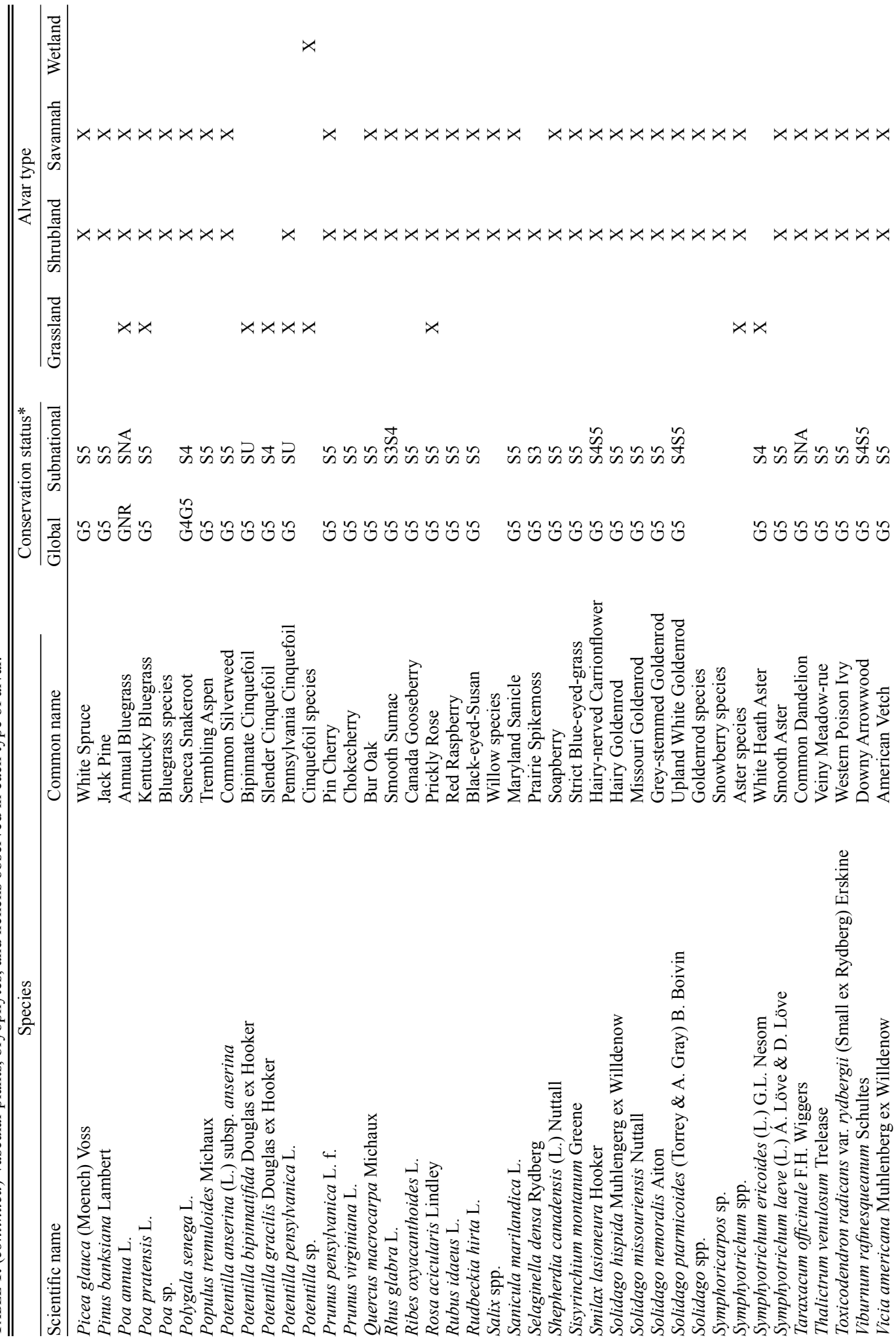




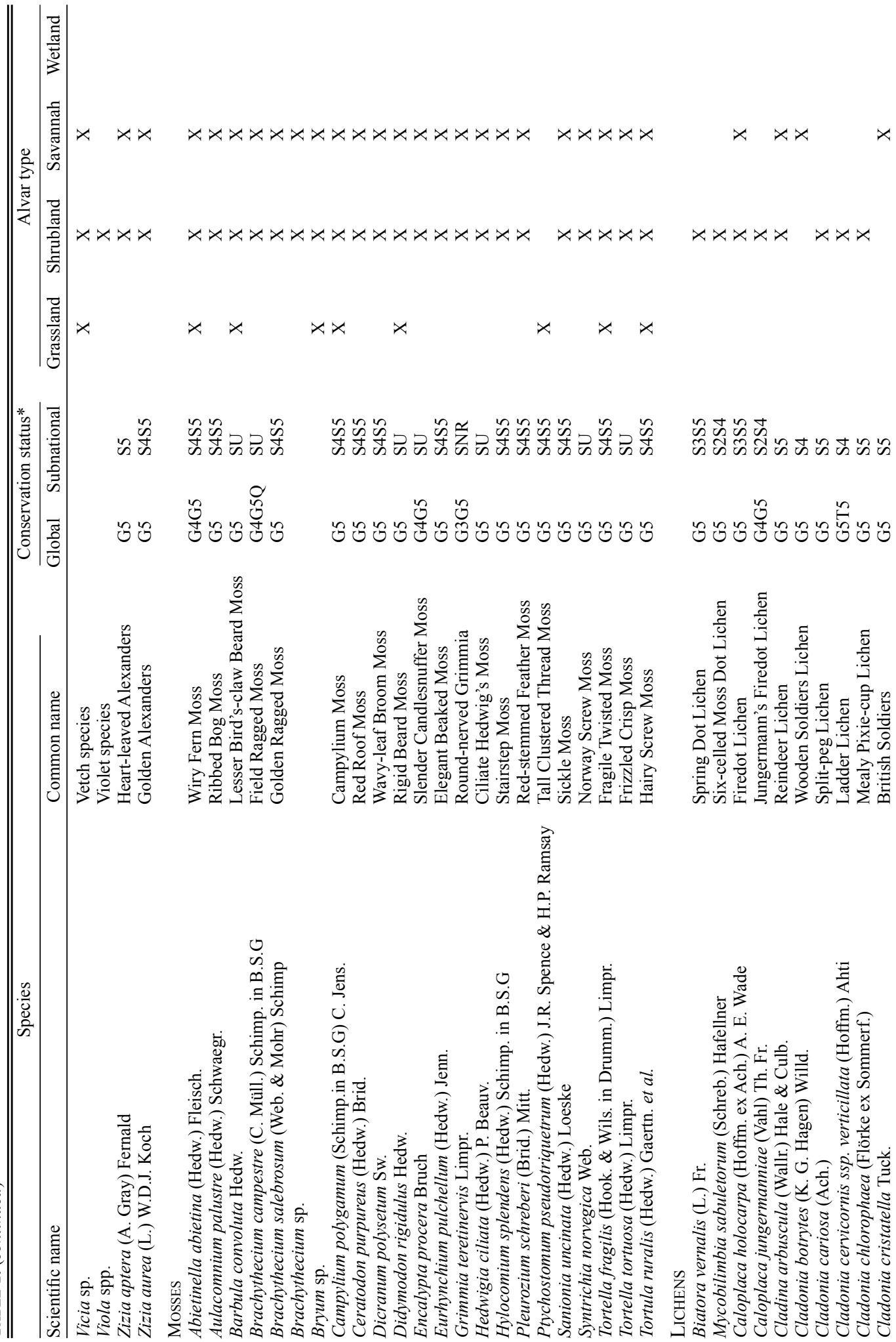




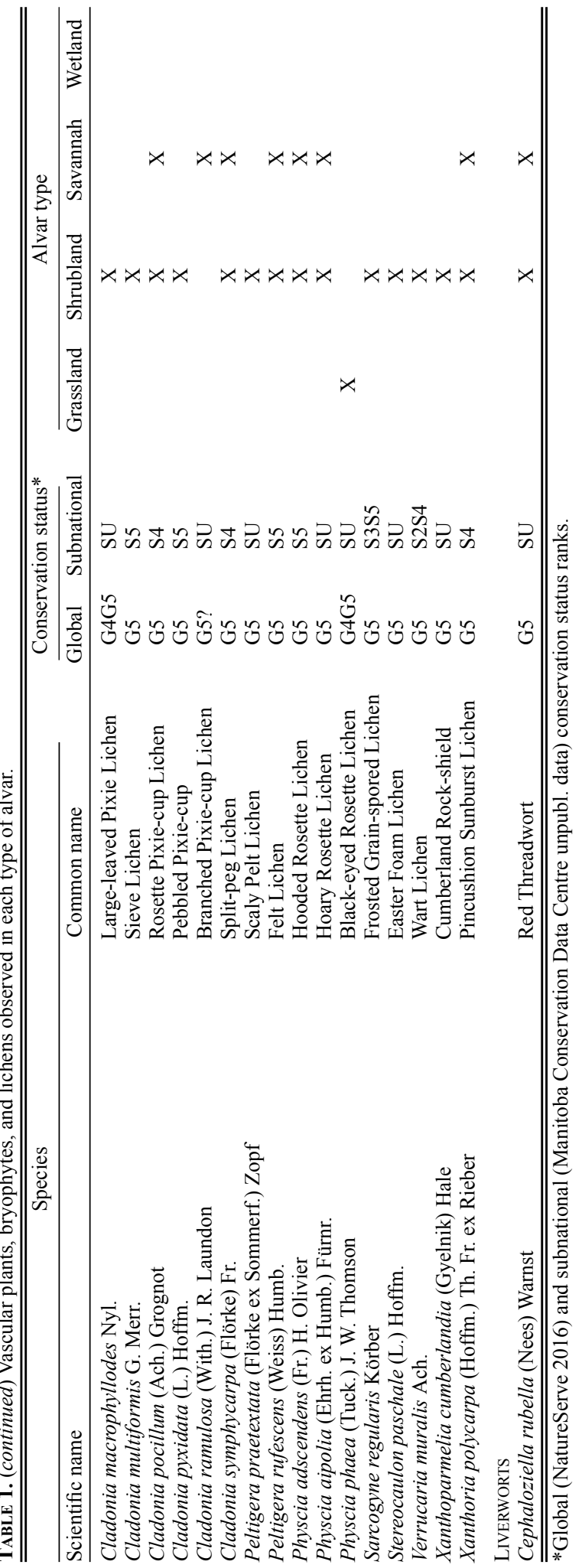




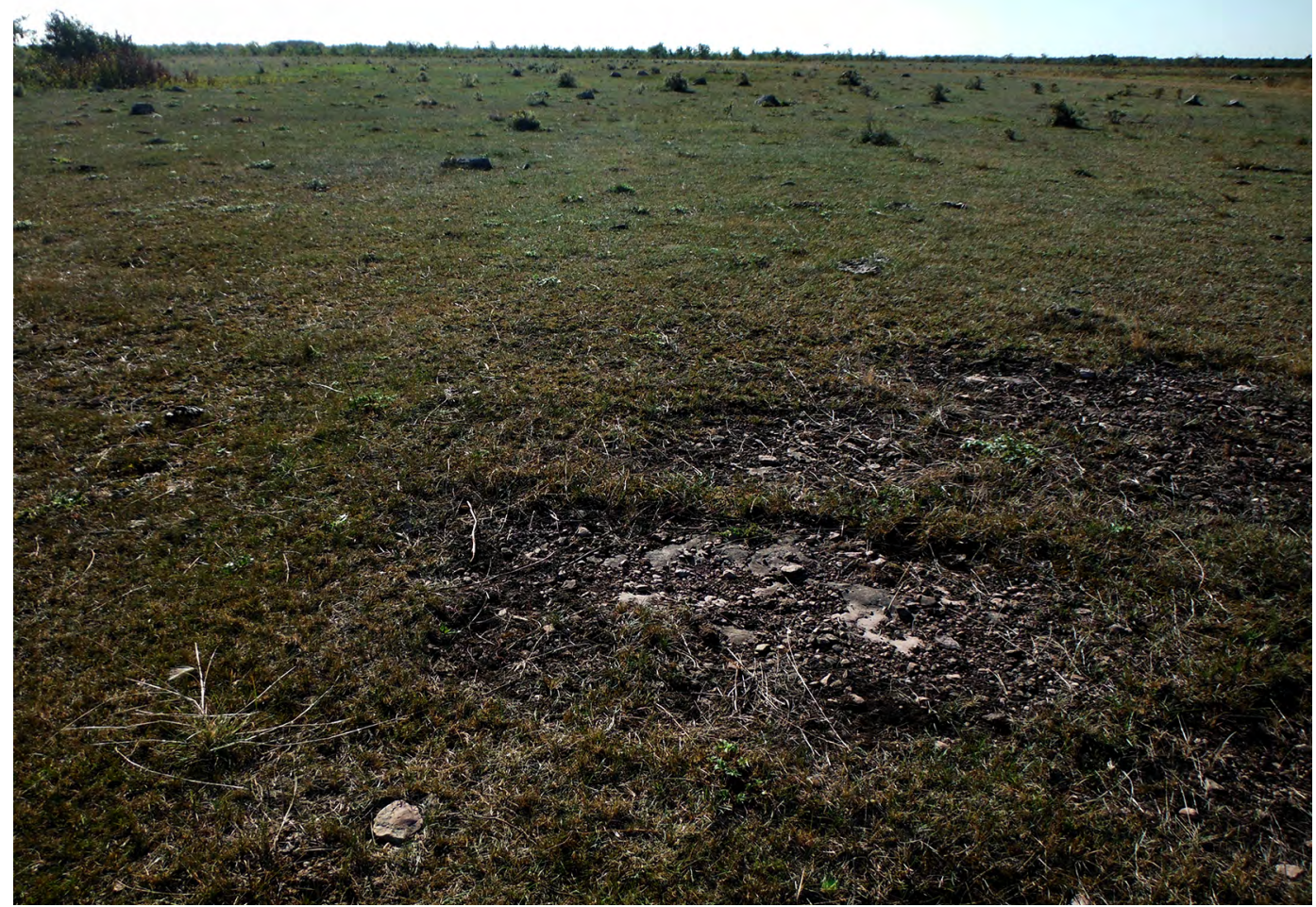

FiguRE 3. Grazed grassland alvar at the Sylvan Alvar site. Photo: Nature Conservancy of Canada.

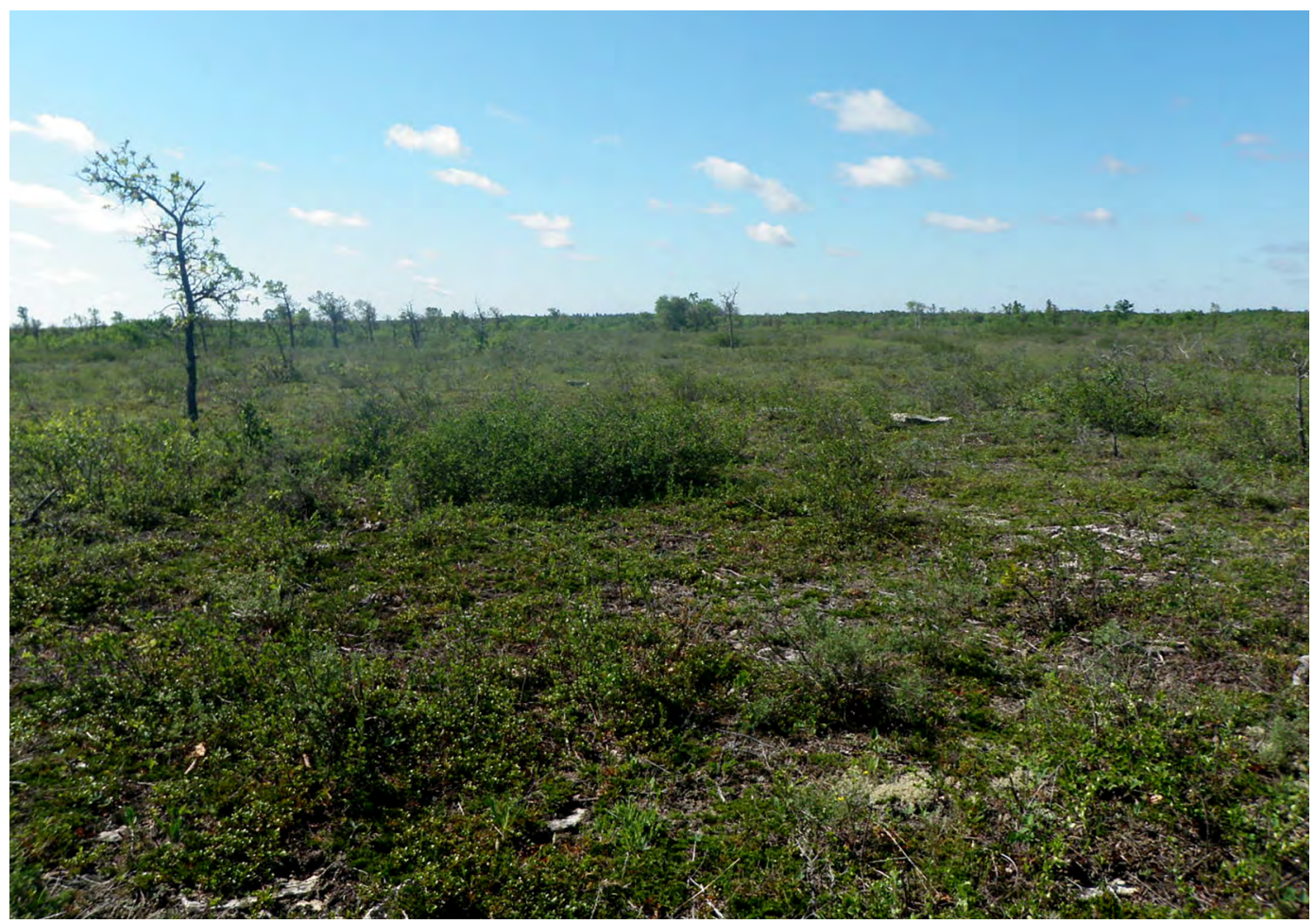

FigurE 4. Shrubland alvar at the Clematis Alvar site. Photo: Nature Conservancy of Canada. 


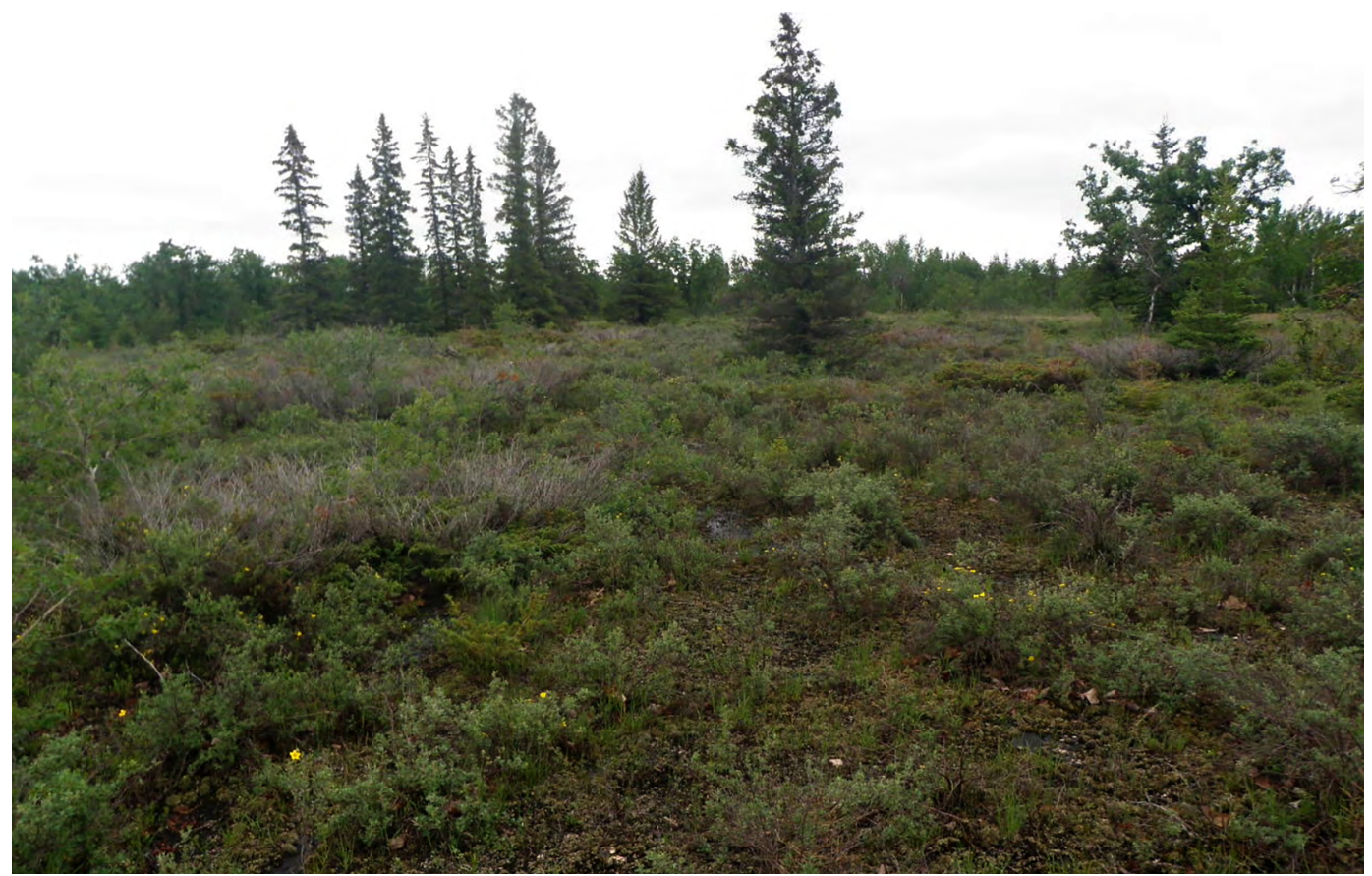

FIGURE 5. At the Clematis Alvar site, trees are often present along the periphery where the alvar transitions into woodland. Photo: Nature Conservancy of Canada.

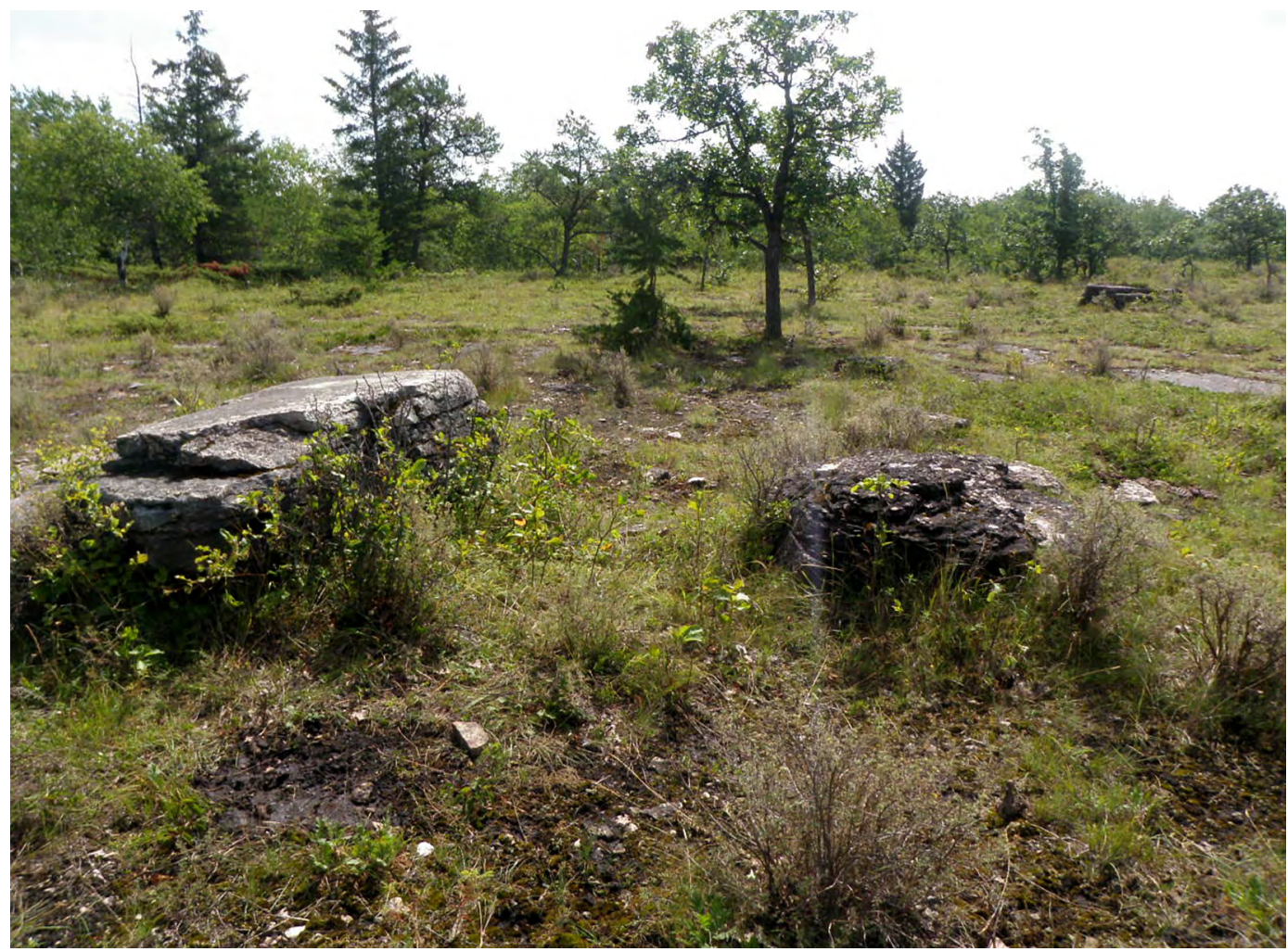

FIGURE 6. Shrubland alvar at the Marble Ridge Alvar site. Some of the scattered boulders support Gastony's Cliffbrake (Pellaea gastonyi) or Western Dwarf Cliffbrake (Pellaea glabella ssp. occidentalis) or both. Photo: Nature Conservancy of Canada. 
than in grassland alvars, although the abundance of each varies among sites. Sites vary from flat to having table-top limestone outcrops and scattered limestone boulders. Drainage is restricted at these sites, which are periodically flooded. In the absence of rain, droughtlike conditions were observed.

Savannah alvars (Figures 7 and 8) are similar to shrubland alvars in their patchy distribution of vegetation. Soil depth is usually $<5 \mathrm{~cm}$, but frequently deeper in cracks and seams. Limestone pavement is frequent. Shrubs are dominant, followed by forbs, with graminoids less abundant. Unlike shrubland alvars, distribution of trees is regular, although still amounting to $<60 \%$ cover, and tall shrubs can occur frequently. Bryophyte and lichen cover is variable and generally less dominant than in shrubland alvars. Like shrubland alvars, savannah alvars vary from being flat to having scattered boulders or table-top outcrops, but are more frequently associated with the latter than shrubland alvars. These sites flood periodically and exhibit droughtlike conditions; however, extremes in moisture variability at sites with greater tree abundance are not as pronounced.

Like grassland alvars, wetland alvars have nearly continuous vegetative cover, with soils about $5 \mathrm{~cm}$ deep and occasional patches of exposed limestone pavement (Figure 9). They are dominated by wetland graminoids and mosses, with few forbs or shrubs and no trees. These are low areas that grade into other alvar types. They are often partly bordered by willow-dominated swamps and marsh. Despite similar soil depths and cover as grassland alvars, these sites remain saturated enough to support wetland vegetation, but are not permanently flooded. It is unknown whether the difference is a result of increased water catchment from the surrounding topography or a difference in the degree of drainage restriction by the underlying bedrock.

\section{Bedrock geology}

Survey sites coincided with limestone bedrock from the Jurassic, Permian, Devonian, Silurian, and Ordovician geologic periods. Alvar was located only on Silurian and Ordovician bedrock, which consist primarily of dolomite (Manitoba Mineral Resources 2012a).

The Clematis Alvar and two units of the Poplarfield Alvar occur on Silurian bedrock, which consists of micritic, fossiliferous, stromatolitic, and biostromal dolomites, whereas the other alvars occur on Ordovician bedrock comprising various dolomites including argillaceous, nodular, and laminated dolomite (Manitoba Mineral Resources 2012a).

Alvars occur on four Ordovician formations. The Marble Ridge Alvar site and the rest of the Poplarfield Alvar sites are primarily located within the western

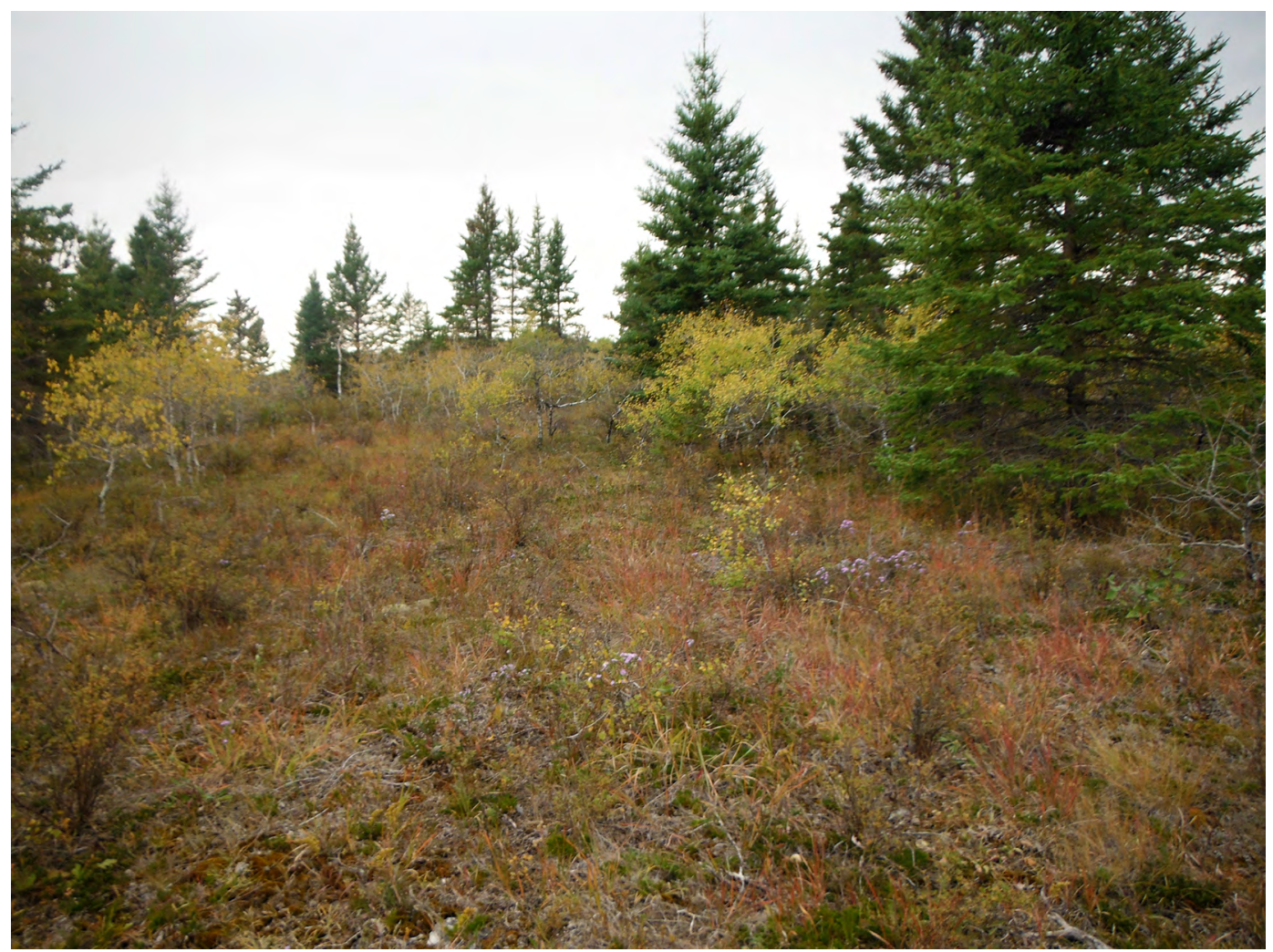

FiguRE 7. Savannah alvar with White Spruce (Picea glauca) at the Poplarfield Alvar site. Photo: Nature Conservancy of Canada. 


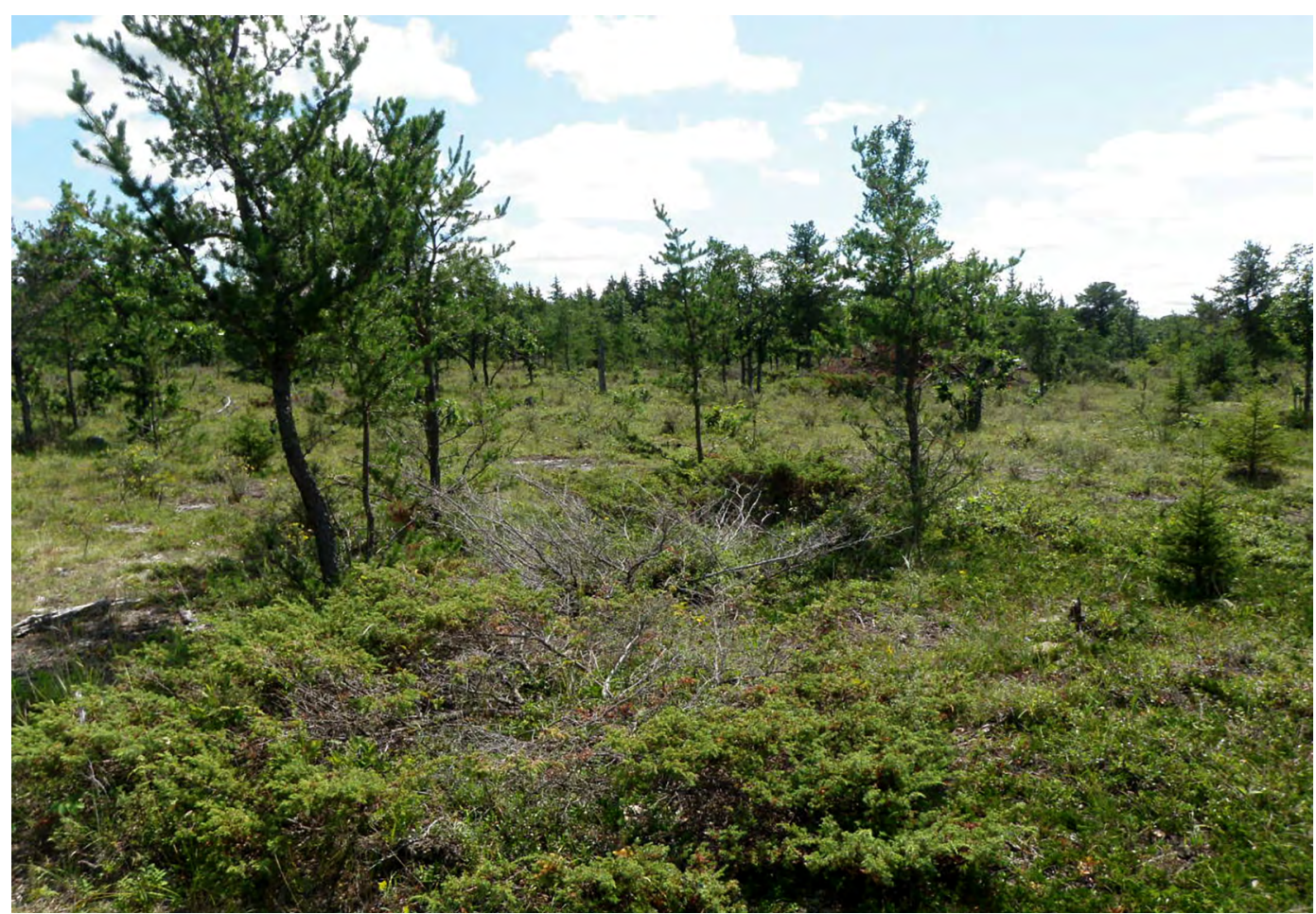

FigURE 8. Savannah alvar with Jack Pine (Pinus banksiana) at the Marble Ridge Alvar site. Photo: Nature Conservancy of Canada.

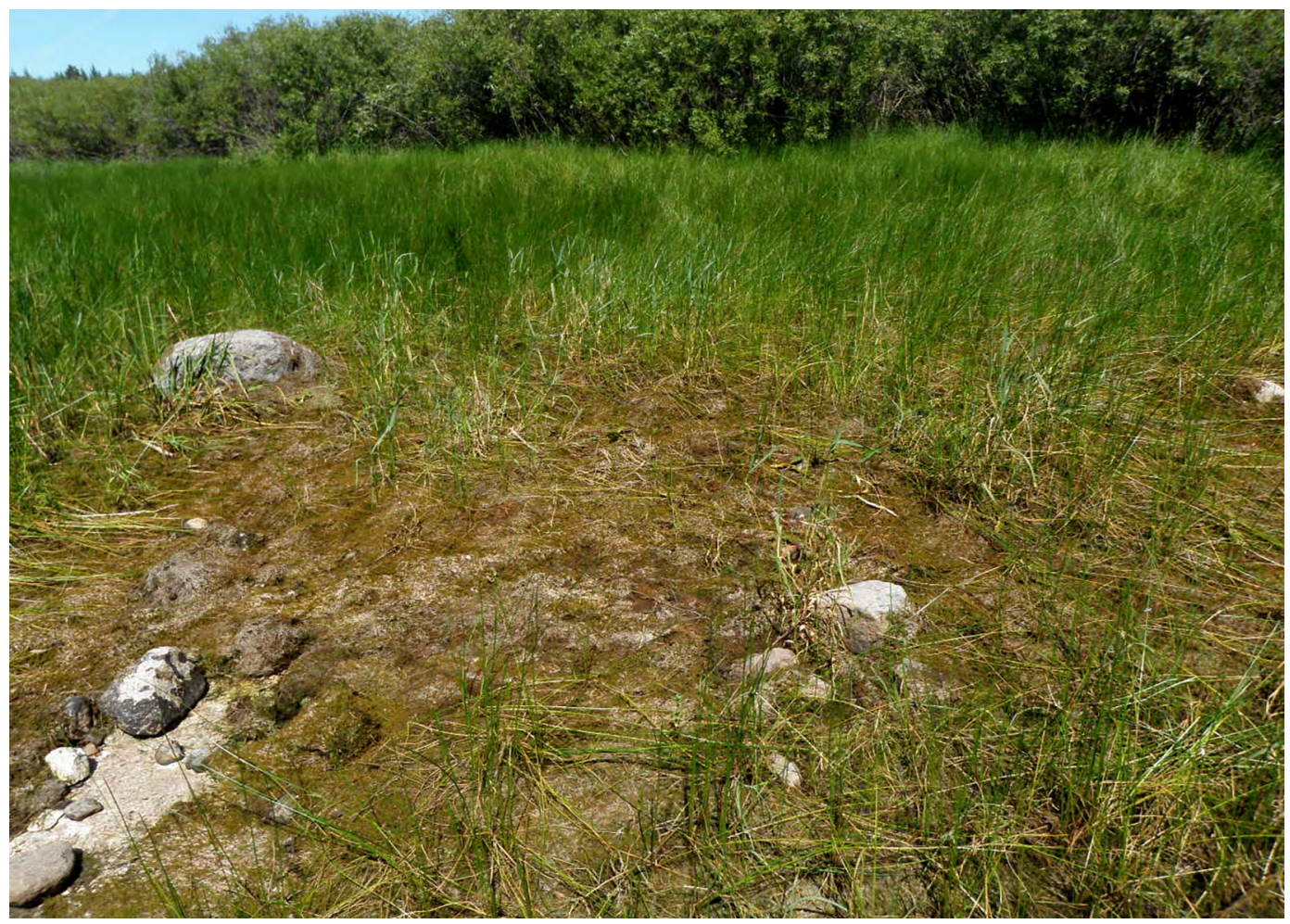

Figure 9. Wetland alvar at the Marble Ridge Alvar site. Photo: Nature Conservancy of Canada. 
Stony Mountain Formation and the East Arm Formation, whereas the Peguis and Sylvan Alvars fall into the eastern Stony Mountain Formation and the Red River Formation (Manitoba Mineral Resources 2012a).

\section{Significant species}

Twenty-four globally, nationally, or provincially rare and uncommon species (NatureServe 2016; Manitoba Conservation Data Centre unpubl. data) were documented at survey sites during this study or previously by Caners (2011). Globally uncommon and provincially endangered Gastony's Cliffbrake (Pellaea gastonyi Windham; Friesen and Murray 2015) and globally uncommon Grimmia Dry Rock Moss (Grimmia teretinervis Limpricht; Caners 2011) were observed growing on limestone cliffs and boulders at the Marble Ridge Alvar sites. Vascular plant species assessed as provincially uncommon or rare (Manitoba Conservation Data Centre unpubl. data) observed during this study include: Dwarf Western Cliffbrake (Pellaea glabella ssp. occidentalis (E.E. Nelson) Windham), Rough Fescue (Festuca hallii (Vasey) Piper), Porter's Chess (Bromus porteri (J.M. Coulter) Nash), Wild White Onion (Allium textile A. Nelson \& J.F. Macbride), Spring Birch (Betula occidentalis Hooker), Spike-oat (Avenula hookeri (Scribner) Holub), American Cow-wheat (Melampyrum lineare Desrousseaux), Large Indian Breadroot (Pediomelum esculentum (Pursh) Rydberg), Smooth Sumac (Rhus glabra L.), and Dense Spikemoss (Selaginella densa Rydberg; Table 1). Six species of lichens observed during this study and six species of bryophytes documented by Caners (2011) are also assessed as nationally or provincially rare or uncommon (NatureServe 2016; Manitoba Conservation Data Centre unpubl. data).

Six non-native plant species were observed in alvars. Timothy (Phleum pratense L.) was observed often, but never as a dominant species. Kentucky Bluegrass (Poa pratensis L.) was observed in some grass-dominated alvars. Annual Bluegrass (Poa annua L.) was observed in some alvars, often occurring on sparsely vegetated patches of shallow, bare soil. Garden Bird's-foot Trefoil (Lotus corniculatus L.) was found on the periphery of two alvars and, at a third site, there were a few scattered plants on the alvar itself. Awnless Brome (Bromus inermis Leysser) and Creeping Bentgrass (Agrostis stolonifera L.) were each observed once in a grazed alvar.

Overall, it appears that non-native species in Manitoba alvars are infrequent, and invasive species that are of high priority for detection and control in Manitoba (Invasive Species Council of Manitoba 2018) are not currently present in these ecosystems. Non-native or invasive plant species can result in reduced biodiversity and function in natural ecosystems and are becoming increasingly widespread in open habitats in the prairie provinces (Canadian Food Inspection Agency 2008; Sinkins and Otfinowski 2012; DeKeyser et al. 2013). The relatively limited presence of non-native or inva- sive species in Manitoba alvars represents a rare opportunity to prevent further establishment and maintain the exceptional biodiversity of these habitats.

\section{Management and conservation context}

Alvars make up $0.3 \%$ (3934 ha) of the south Interlake. Each alvar type supports its own complement of plants and contributes uniquely to the biological diversity of Manitoba. The significance of alvar habitat and the threats it faces across Canada have been extensively documented (Catling and Brownell 1995, 1999b; Reschke et al. 1999; Catling 2014; Catling et al. 2014; Brunton and Catling 2017). Protection and conservation efforts in Manitoba should initially focus on preserving representatives of each type. In addition to supporting vascular plant species assemblages distinct from other ecosystems in Manitoba, different types of alvar support a range of other species groups. For example, we observed grassland-obligate birds, a group undergoing steep population declines in North America (North American Bird Conservation Initiative 2016), on grassland alvars; Eastern Whip-poor-will (Antrostomus vociferus) and Common Nighthawk (Chordeiles minor), both threatened species (SARA Registry 2018a,b), have been documented in shrubland and savannah alvars with sparse vegetation (Manitoba Conservation Data Centre unpubl. data). Alvars associated with inland cliffs, outcrops, and boulders, such as along Marble Ridge, provide a wide range of microhabitats not found in other alvar types, and support a number of bryophytes that are expected to remain uncommon in the region (Caners 2011).

Approximately one third (1261 ha) of alvar in Manitoba occurs on privately owned land, with the remainder on public land including wildlife management areas, community pastures, and undesignated provincial Crown land.

No alvar sites identified in this study are located within the boundaries of protected areas (IUCN Protected Areas Classification level IV or higher; Manitoba Conservation and Water Stewardship 2012b) or are protected from all types of development. A 2560-ha ecosystem protection zone that encompasses most of the Marble Ridge Alvar site has been proposed.

Approximately $12 \%$ of the Manitoba alvar habitat identified in this study falls under mining and/or quarry leases (Manitoba Mineral Resources 2012b) and, thus, may be exposed to habitat destruction from mining activities. At the time of our survey, near-surface limestone had been commercially extracted immediately adjacent to or within alvar communities at six locations.

Approximately 76\% (2985 ha) of alvar habitat identified in this study was being grazed at the time of the survey or exhibited signs of having been grazed recently. Another 11\% (432 ha) did not appear to be grazed by domestic livestock. Most observed grazing animals were cattle, but horses and bison were also observed. Land use at the other locations (13\%) could not be determined. Pre-European settlement grazing histories for 
the Interlake area are unclear (Henderson and Koper 2014), but grazing by large ungulates has likely always contributed to the disturbance regime of Manitoba alvars and may play an important role in maintaining their openness, as it does in alvars elsewhere (Reschke et al. 1999). However, current grazing management using livestock is unlikely to mirror historical patterns (Henderson and Koper 2014), and grazing at incompatible frequencies, intensities, or durations may result in alterations to species composition and facilitate the spread of non-native species (Reschke et al. 1999).

No evidence of recent natural fire, an important ecological requirement of many alvar habitats (Catling and Brownell 1998; Catling et al. 2002; Jones and Reschke 2005; Catling 2009b), was observed in or near any of the alvars. Trembling Aspen (Populus tremuloides Michaux) encroachment was observed at some locations in the Clematis Alvar and Poplarfield Alvar sites. Longterm fire suppression is probably negatively impacting the ecological integrity and biodiversity of alvar habitat here, as it is in other open habitats in southern Manitoba (e.g., Koper et al. 2010) and throughout North America.

The current mix of public and private land ownership, history of fire suppression, and the economic potential of alvars for grazing and mineral resources highlight the need for the involvement and cooperation of a range of stakeholders, including industry and private landowners, in alvar conservation.

\section{Further research}

This study presents only a first approximation of the various types of alvar present in Manitoba, and there is a need for classification of alvar habitat in the province using a quantitative data-based scheme. This would help to refine the conservation status of alvar types/subtypes and to inform site-condition metrics, compatible landmanagement activities, and conservation opportunities. Faunal surveys to further assess the biodiversity of these sites are also needed. The selection of appropriate conservation management options in Manitoba requires full investigation of the relation between the ecological integrity of alvar habitat and ecological processes, such as grazing and fire suppression.

\section{Acknowledgements}

A grant from the Province of Manitoba to the Nature Conservancy of Canada (NCC) supported NCC staff. R.N.'s 2012 field activities were supported by a Shell Conservation Internship. Manitoba Sustainable Development provided field support for C.F. through the Endangered Species and Biodiversity Fund. Bryana Nicolas, Carly Dow, and Chris Hay from NCC and Colin Murray from the Critical Wildlife Habitat Program assisted with field surveys. Our thanks to the private landowners who provided access to and information about alvar habitat on their land. Stephen Gietz from NCC provided GIS expertise and support. Helios Hernandez (Manitoba Association of Plant Biologists) and Nicole Firlotte (Manitoba Sustainable Development) provided their expertise and support as members of the Manitoba Alvar Initiative Steering Committee. An earlier version of this manuscript was reviewed by Nicolas LaPointe and Melissa Grantham of NCC. The authors gratefully acknowledge Richard Caners (Royal Alberta Museum) and Michele Piercey-Normore (University of Manitoba) for bryophyte and lichen identification, respectively. Our thanks to reviewers Daniel Brunton and Pauline Catling, whose comments greatly improved the manuscript.

\section{Literature Cited}

Brunton, D.F. 1988. The Clay Bank Alvar. Trail \& Landscape 22: 53-65. Accessed 21 January 2018. http://www.biodiver sitylibrary.org/item/202202\#page/23/mode/1up.

Brunton, D.F., and P.M. Catling. 2017. Thematic collection: alvars in Canada. Canadian Field-Naturalist 131: 75-79. https://doi.org/10.22621/cfn.v131i1.1962

Canadian Food Inspection Agency. 2008. Invasive alien plants in Canada - Technical Report. CFIA. Ottawa, Ontario, Canada. Accessed 30 January 2018. http://epe.lac-bac.gc.ca/ 100/206/301/cfia-acia/2011-09-21/www.inspection.gc.ca/ english/plaveg/invenv/techrpt/techrese.shtml.

Caners, R.T. 2011. Saxicolous bryophytes of an Ordovician dolomite escarpment in Interlake Manitoba, with new species records for the province. Canadian Field-Naturalist 125: 327-337. https://doi.org/10.22621/cfn.v125i4.1261

Catling, P.M. 2009a. Composition, phytogeography, and relict status of the vascular flora of alvars and cliff tops southwest of Great Slave Lake, Northwest Territories, Canada. Rhodora 111: 189-208. https://doi.org/10.3119/08-33.1

Catling, P.M. 2009b. Vascular plant diversity in burned and unburned alvar woodland: more evidence of the importance of disturbance to biodiversity and conservation. Canadian Field-Naturalist 123: 240-245. https://doi.org/10.22621/ cfn.v123i3.971

Catling, P.M. 2014. Impact of the 2012 drought on woody vegetation invading alvar grasslands in the Burnt Lands Alvar, eastern Ontario. Canadian Field-Naturalist 128: 243249. https://doi.org/10.22621/cfn.v128i3.1602

Catling, P.M., and V.R. Brownell. 1995. A review of the alvars of the Great Lakes region - distribution, floristic composition, biogeography and protection. Canadian Field-Naturalist 109: 143-171. Accessed 21 January 2018. http://bio diversitylibrary.org/page/35456991.

Catling, P.M., and V.R. Brownell. 1998. Importance of fire in alvar ecosystems - evidence from the Burnt Lands, eastern Ontario. Canadian Field-Naturalist 112: 661-667. Accessed 21 January 2018. http://biodiversitylibrary.org/page/ 34258017.

Catling, P.M., and V.R. Brownell. 1999a. An objective classification of Ontario plateau alvars in the northern portion of the Mixedwoods Plains Ecozone and a consideration of protection frameworks. Canadian Field-Naturalist 113: 569575. Accessed 21 January 2018. https://biodiversitylibrary. org/page/34235439.

Catling, P.M., and V.R. Brownell. 1999b. Additional notes on the vegetation of dry openings along the Trent River, Ontario. Canadian Field-Naturalist 113: 506-509. Accessed 30 January 2018. http://biodiversitylibrary.org/page/34235372.

Catling, P.K., P.M. Catling, J. Cayouette, M. Oldham, B. Ford, C. Hamel, and C. Friesen. 2014. Canadian alvars and limestone barrens: areas of "special conservation con- 
cern" for plants? Canadian Botanical Association Bulletin 47: 9-11. Accessed 21 June 2018. http://www.cba-abc.ca/ bulletinMarch2014.pdf.

Catling, P.M., A. Sinclair, and D. Cuddy. 2002. Plant community composition and relationships of disturbed and undisturbed alvar woodland. Canadian Field-Naturalist 116: 571-579. Accessed 21 January 2018. https://biodiversitylib rary.org/page/35151817.

DeKeyser, E.S., M. Meehan, G. Clambey, and K. Krabbenhoft. 2013. Cool season invasive grasses in northern Great Plains natural areas. Natural Areas Journal 33: 18-90. https: //doi.org/10.3375/043.033.0110

Friesen, C., and C. Murray. 2015. Gastony's Cliffbrake (Pellaea gastonyi) in Manitoba: new records and assessment of conservation status. Canadian Field-Naturalist 129: 45-52. https://doi.org/10.22621/cfn.v129i1.1666

Hamel, C., and C. Foster. 2004. Surveys of a rare alvar-like plant community in eastern Clematis WMA and comments on regional significance. Manitoba Conservation Data Centre, Winnipeg, Manitoba, Canada.

Henderson, D.C., and N. Koper. 2014. Historic distribution and ecology of tall-grass prairie in western Canada. Proceedings of the North American Prairie Conference 23: 40 49. Accessed 24 January 2018. https://greatplainsnaturalsci encesociety.files.wordpress.com/2017/01/pdf-hendersonnapc.pdf.

Invasive Species Council of Manitoba. 2018. Terrestrial species. ISCM, Winnipeg, Manitoba, Canada. Accessed 30 January 2018. http://invasivespeciesmanitoba.com/site/index. php?page $=$ terrestrial-species.

Jones, J., and C. Reschke. 2005. Role of fire in Great Lakes alvar landscapes. Michigan Botanist 44: 13-27. Accessed 20 January 2018. https://quod.lib.umich.edu/m/mbot/0497 763.0044.105/1.

Koper, N., K.E. Mozel, and D.C. Henderson. 2010. Recent declines in northern tall-grass prairies and effect of patch structure on community persistence. Biological Conservation 143: 220-229. https://doi.org/10.1016/j.biocon.2009. 10.006

Manitoba Alvar Initiative. 2012. Alvars in Manitoba: a description of their extent, characteristics and land use. Nature Conservancy of Canada, Manitoba Region, Winnipeg, Manitoba and Manitoba Conservation and Water Stewardship. Accessed 21 January 2018. http://www.natureconservancy. $\mathrm{ca} /$ assets/documents/mb/2012-Alvar-Initiative-FINAL-Re port-PUBLIC-DISTRIBUTION-Jan-2013.pdf.

Manitoba Conservation and Water Stewardship. 2012a. Digital Elevation Models - DEMs Shapefile. Manitoba land initiative. Conservation and Water Stewardship, Winnipeg, Manitoba, Canada. Accessed 12 October 2012. http://mli2. gov.mb.ca/dems/index.html.
Manitoba Conservation and Water Stewardship. 2012b. Protected Areas Shapefile. Manitoba land initiative. Conservation and Water Stewardship, Winnipeg, Manitoba, Canada. Accessed 12 October 2012. http://mli2.gov.mb.ca/ adminbnd/index.html.

Manitoba Mineral Resources. 2012a. Bedrock geology, Manitoba; in Map Gallery - Geological Map of Manitoba. Manitoba Mineral Resources, Winnipeg, Manitoba, Canada. Accessed 18 October 2012. https://web33.gov.mb.ca/map gallery/mgg-gmm.html.

Manitoba Mineral Resources. 2012b. Mineral dispositions, Manitoba; in Map Gallery - Mineral Dispositions. Manitoba Mineral Resources, Winnipeg, Manitoba, Canada. Accessed 18 October 2012. https://web33.gov.mb.ca/mapgallery/mgm-md.html.

Minnesota Department of Natural Resources. 2005. Field Guide to the Native Plant Communities of Minnesota: The Prairie Parkland and Tallgrass Aspen Parklands Provinces. Ecological Land Classification Program, Minnesota County Biological Survey, and Natural Heritage and Nongame Research Program, MNDNR, St. Paul, Minnesota, USA.

NatureServe. 2016. NatureServe conservation status. NatureServe, Arlington, Virginia, USA. Accessed October 2016. http://explorer.natureserve.org/ranking.htm.

North American Bird Conservation Initiative. 2016. Oiseaux. Birds. Aves. NABCI, Cornell Lab, Ithaca, New York, USA. Accessed 30 January 2018. http://www.stateofthebirds.org/2016/wp-content/uploads/2016/05/SotB_16-0426-ENGLISH-BEST.pdf.

Reschke, C., R. Reid, J. Jones, T. Feeney, and H. Potter. 1999. Conserving Great Lakes alvars: final technical report of the International Alvar Conservation Initiative. Nature Conservancy (Great Lakes Program), Chicago, Illinois, USA. Accessed 21 January 2018. https://archive.epa.gov/ ecopage/web/pdf/alvar-technical-report-199903.pdf.

SARA (Species at Risk) Registry. 2018a. Species profile: Eastern Whip-poor-will. Environment and Climate Change Canada, Gatineau, Quebec, Canada. Accessed 30 January 2018. http://sararegistry.gc.ca/species/speciesDetails_e.cfm ?sid=1047.

SARA (Species at Risk) Registry. 2018b. Species profile: Common Nighthawk. Accessed 30 January 2018. http://sara registry.gc.ca/species/speciesDetails_e.cfm?sid=986.

Sinkins, P.A., and R. Otfinowski. 2012. Invasion or retreat? The fate of exotic invaders on the northern prairie, 40 years after cattle grazing. Plant Ecology 213: 1251-1262. http:// doi.org/10.1007/s11258-012-0083-8

Received 15 October 2016

Accepted 10 May 2018 